\title{
PERLINDUNGAN HUTAN \\ MELALUI KEARIFAN LOKAL
}

\section{Oleh: Gurniwan Kamil Pasya}

\begin{abstract}
ABSTRAK
Kerusakan hutan di Indonesia sudah sangat parah sebagai akibat banyak perusahaan kayu yang membabat hutan secara besar-besaran, pencurian tanpa kendali, bahkan kebakaran hutan, akibatnya luas hutan setiap tahun semakin berkurang, sedangkan usaha untuk penghutanan kembali tidak seimbang dengan banyaknya pohon yang hilang. Karena itu, kita harus bercermin dari masyarakat adat yang memiliki kearifan dalam memelihara dan melindungi hutan, mereka membagi hutan sesuai dengan peruntukkannya, bahkan di dalam kehidupan mereka terdapat hutan lindung yang pohonnya dilarang untuk ditebang untuk alasan apapun. Walaupun demikian, aturan adat yang dilaksanakan secara turun temurun tidak akan berdaya menghadapi rongrongan dari luar terhadap hutan mereka, sehingga perlu adanya campur tangan dari pemerintah untyuk mengakui keberadaan mereka beserta hutannya melalui peraturan yang jelas. Hutan sebagai bagian dari lingkungan hidup masyarakat adat jangan sampai terjadi penurunan kualitas, karena akan menurunkan kualitas hidup mereka. Dengan demikian, untuk meningkatkan kualitas hidup masyarakat adat di antaranya melalui pengakuan hak kehutanan agar kualitas lingkungannya menjadi lebih baik dan optimal, sehingga mereka tetap bertahan hidup dan berkesinambungan.
\end{abstract}

Kata kunci: Kearifan lokal, sistem nilai, etika lingkungan.

*) Dr. Gurniwan Kamil Pasya, M.Si., adalah dosen Jurusan Pendidikan Geografi FPIPS UPI. 


\section{Pendahuluan}

Bencana alam terjadi di mana-mana berupa banjir, lonsor, kebakaran hutan dan lain-lain, sehingga menjadikan pertanyaan bagi kita "mengapa hal itu terjadi?" apabila kita telusuri maka hal tersebut, kembali kepada manusia sendiri yang menyebabkannya, seperti pengambilan kayu hutan secara tidak terkendali, terutama banyaknya pembalakan liar oleh oknum yang tidak bertanggung jawab apalagi yang bersangkutan memiliki kekuasaan. Dengan demikian, bahwa hutan memiliki peranan penting dalam kehidupan, terutama dalam hal menjaga tata air dan menjaga terjadinya bencana alam.

Nampaknya usaha untuk menghutankan kembali tidak seimbang dengan banyaknya kayu yang diambil dari hutan yang akibatnya hutan Indonesia setiap tahun terus berkurang, padahal hutan dianggap sebagai paru-paru bumi dan penghasil $\mathrm{O}_{2}$ yang terbesar. Berkurangnya hutan banyak diakibatkan oleh kebakaran terjadi di Indonesia setiap tahun tepatnya terjadi pada setiap musim kemarau, menurut beberapa pendapat disebabkan oleh sistem perladangan yang dilakukan masyarakat sekitarnya dalam membuka ladang terlebih dahulu membakar hutan, "apakah demikian ?" pendapat ini banyak dibantah, karena masyarakat yang melakukan perladangan hanya membakar hutan secara terbatas dan wilayah yang dibakar terlebih dahulu menebang pohon yang mengelilingi bakal ladang, sehingga jika dilakukan pembakaran maka api dapat dikendalikan. Di samping itu adapula yang terlebih dahulu membabat pohon di lahan-lahan bakal ladang, pohon dimanfaatkan untuk berbagai keperluan sedangkan daun dan rantingnya yang dianggap tidak bermanfaat ditumpuk sampai kering kemudian dibakar. Tetapi adapula pendapat yang paling menonjol dalam hal pembakaran hutan, yaitu dilakukan oleh pengusaha kayu atau perkebunan, terlebih dahulu menyuruh orang untuk membakar hutan, akibatnya terjadi kebakaran hutan yang sangat luas seperti terjadi di Pulau Sumatera, Pulau Kalimantan dan pulau lainnya menyebabkan terjadinya kabut asap yang mengganggu pernafasan dan mengganggu penerbangan di pulau-pulau tersebut, bahkan sampai ke negara tetangga. Tujuan pembakaran hutan seperti ini jelas untuk memperluas areal perkebunan dan menghindari kewajiban untuk melakukan penanaman kembali bagi perusahaan kayu. Pelaku pembakar hutan sebagai orang suruhan pernah ditangkap tetapi orang yang menyuruhnya tidak ada berita ditangkap dan diadili, sehingga kebakaran hutan yang dianggap secara sengaja akan terus terjadi.

Banjir di mana-mana terjadi setiap musim penghujan akibat meluapnya sungai, karena di bagian hulu tidak ada penahan yang meresapkan air hujan ke dalam tanah, air limpasan secara langsung mengisi lembah-lembah sungai, sehingga terjadilah banjir kiriman seperti hujan di Bogor dan banjir terjadi di Jakarta. Selain terjadi banjir akibat meluapnya sungai di musim penghujan, juga terjadinya kekeringan di musim kemarau karena kurangnya air yang tertahan oleh akar pohon di hutan akibat penebangan yang tidak terkendali. Bencana banjir dan longsor yang terjadi setiap tahun, mulai sekarang perlu ditangani oleh berbagai pihak terutama menumbuhkan kesadaran akan pentingnya hutan, bagi mereka yang ada di hulu sungai dan yang berhubungan dengan hutan. Pentingnya hutan bagi kehidupan tampaknya harus bercermin dari masyarakat adat yang senantiasa menjaga hutan sebagai salah satu usaha untuk mempertahankan kehidupan mereka. 


\section{Kearifan Lokal}

Masyarakat adat yang mempertahankan hutan sebagai bagian dari kehidupan mereka, akan dilindungi dengan beberapa cara yang kita anggap tidak masuk akal seperti jangan mengambil kayu di hutan karena akan menyebabkan marahnya mahluk ghaib penunggu hutan; masuk hutan tidak boleh ribut jika tidak ingin terkena musibah; dilarang masuk hutan jika ingin selamat; dilarang mengambil daun atau ranting di hutan jika tidak ingin diikuti oleh mahluk ghaib sampai ke rumah; dan larangan-larangan lain yang dapat menyebabkan kerusakan hutan. Perlindungan hutan seperti itu, merupakan salah satu perlindungan yang sampai sekarang dianggap efektif, sehingga kelestarian hutan tetap terjaga dibandingkan dengan adanya Undang-Undang dan sanksi hukum yang jelas bagi pelanggarnya, tetapi bagi masyarakat adat yang berhubungan dengan hutan menganggap bahwa hutan sebagai titipan dari karuhun (leluhur atau nenek moyang) yang harus dijaga apabila masih menginginkan kehidupannya terus berkelanjutan. Melindungi hutan dengan cara tersendiri yang dilakukan oleh masyarakat adat, merupakan suatu etika yang harus dilaksanakan dan sebagai bagian dari norma adat yang mereka miliki. Sehubungan dengan etika lingkungan, Soerjani dkk (1987 : 15) mengemukakan sebagai berikut :

... etika lingkungan merupakan petunjuk atau perilaku praktis manusia dalam mengusahakan terwujudnya moral lingkungan. Dengan etika lingkungan kita tidak saja mengimbangi hak dengan kewajiban terhadap lingkungan, tetapi etika lingkungan juga membatasi tingkah laku dan upaya untuk mengendalikan berbagai kegiatan agar tetap berada dalam batas kelentingan hidup kita.

Melalui etika lingkungan niscaya hutan akan tetap terjaga dan terpelihara kelestariannya. Karena itu, etika lingkungan yang dijalankan oleh masyarakat adat melalui tradisi sebagai warisan budaya.

Dengan demikian, bahwa etika lingkungan yang terbentuk di dalam kehidupan sebagai hasil dari kebudayaan dianggap memiliki nilai yang tinggi, sehingga harus dijalankan. Dalam hal ini etika lingkungan dapat dimasukkan ke dalam sistem nilai budaya seperti dikemukakan Daeng (2000 : 46) sebagai berikut:

... Sebagai inti dari sistem kebudayaan, sistem nilai budaya menjiwai semua pedoman yang mengatur tingkah laku warga pendukung kebudayaan yang bersangkutan. Pedoman tingkah laku itu adalah adat istiadat, sistem normanya, aturan etikanya, aturan moralnya, aturan sopansantunnya, pandangan hidup, ideologi pribadi.

Manusia akan mengembangkan sistem nilai budaya yang berhubungan dengan lingkungan terutama hutan, apabila hutan tersebut dirasakan daya dukungnya sudah semakin menurun dan berada pada batas yang dianggap dapat menggoyahkan kehidupan mereka, maka diperlukan usaha untuk menjaga perilaku masyarakat adat yang dapat merugikan lingkungan dan manusia lainnya. Dengan demikian, kearifan lokal sebagai usaha untuk menjaga dan melindungi hutan yang dimiliki oleh masyarakat adat sebagai bentuk dari etika lingkungan.

Untuk melindungi hutan yang dilakukan oleh masyarakat adat dengan membagi hutan menjadi menjadi beberapa bagian, seperti yang dilakukan oleh : 
Masyarakat adat yang berada di kecamatan Cisolok Kabupaten Sukabumi disebut komunitas Kasepuhan Banten Selatan, mereka telah membagi hutan ke dalam tiga klasifikasi, yaitu :

(1) Leuweung sampalan, yaitu hutan yang boleh dieksploitasi untuk berbagai kebutuhan, perladangan, dan pemeliharaan ternak (pangangonan = penggembalaan);

(2) Leuweung geledegan, yaitu hutan yang tidak boleh dieksploitasi, baik untuk kepentingan perorangan, masyarakat, ataupun kepentingan tradisi (adat) sehingga hutan ini harus tetap sebagaimana adanya. Hutan ini dijaga karena dianggap sebagai hutan yang dapat menjaga tata air dan pengatur iklim mikro;

(3) Leuweung titipan, yaitu hutan yang boleh dieksploitasi setelah adanya ijin dari pimpinan adat, hutan titipan dapat juga disebut sebagai hutan cadangan. Pemanfaatan hutan ini dilakukan secara ketat, baik untuk pengambilan kayu ataupun sumberdaya hutan yang terdapat di dalamnya. Kayu yang boleh diambil hanya untuk kepentingan pembuatan rumahrumah warga kasepuhan, itupun apabila tidak dapat diperoleh kayu dari hutan lain (leuweung sampalan).

\section{2) Komunitas Baduy}

Masyarakat adat Baduy berada di Desa Kanekes, Kabupaten Lebak Banten, tepatnya berada di hulu Ci Ujung yang bermuara di teluk Banten. Komunitas Baduy membagi hutan menjadi :

(1) Hutan lindung atau leuweung kolot. Hutan ini terdapat di tempat-tempat tertentu seperti pada puncak-puncak perbukitan, lembah tempat keluarnya mata air. Leuweung kolot merupakan hutan yang kayunya dilarang ditebang dan dimanfaatkan untuk berbagai kebutuhan, karena selain berfungsi untuk mengatur iklim mikro juga untuk mengatur tata air di Desa Kanekes. Di dalam hutan ini terdapat pohon-pohon yang memiliki umur cukup tua, juga terdapat pohon buah-buahan yang dapat dimanfaatkan;

(2) Reuma atau hutan muda. Hutan muda ini akan tumbuh di bekas lahan huma (ladang) yang ditinggalkan dalam jangka waktu yang relatif lama, tetapi apabila rotasi huma menjadi relatif pendek atau kurang dari 4 tahun maka lahan tidak akan sempat untuk menjadikannya hutan malahan menjadi semak atau belukar. Sekarang ini, reuma digunakan untuk penanaman pohon jenjeng (albazia) selain berumur pendek sesuai dengan siklus huma, kayunya dapat dimanfaatkan atau dijual, juga dapat menyuburkan tanah;

(3) Leuweung lembur. Merupakan pohon-pohon yang relatif besar berada di sekitar pemukiman atau kampung Orang Baduy, menjadikan beberapa kampung Baduy dari kejauhan tidak kelihatan tersamar oleh pohon yang menghalanginya. Pohon-pohon di sekitar kampung ini kadangkala tidak dapat disebut hutan mengingat pohon di sekitar rumah atau kampung berfungsi sebagai peneduh di saat siang hari di mana udara sedang panas-panasnya. Pohon-pohon yang terdapat di sekitar pemukiman berupa pohon buah-buahan atau pohon lain yang kayunya dimanfaatkan untuk bahan rumah atau dijadikan perlengkapan kebutuhan sehari-hari seperti, lesung untuk menumbuk padi, lesung untuk menampung air di 
dekat mata air, peti untuk menyimpan perabot, peralatan dapur, dan lainlain.

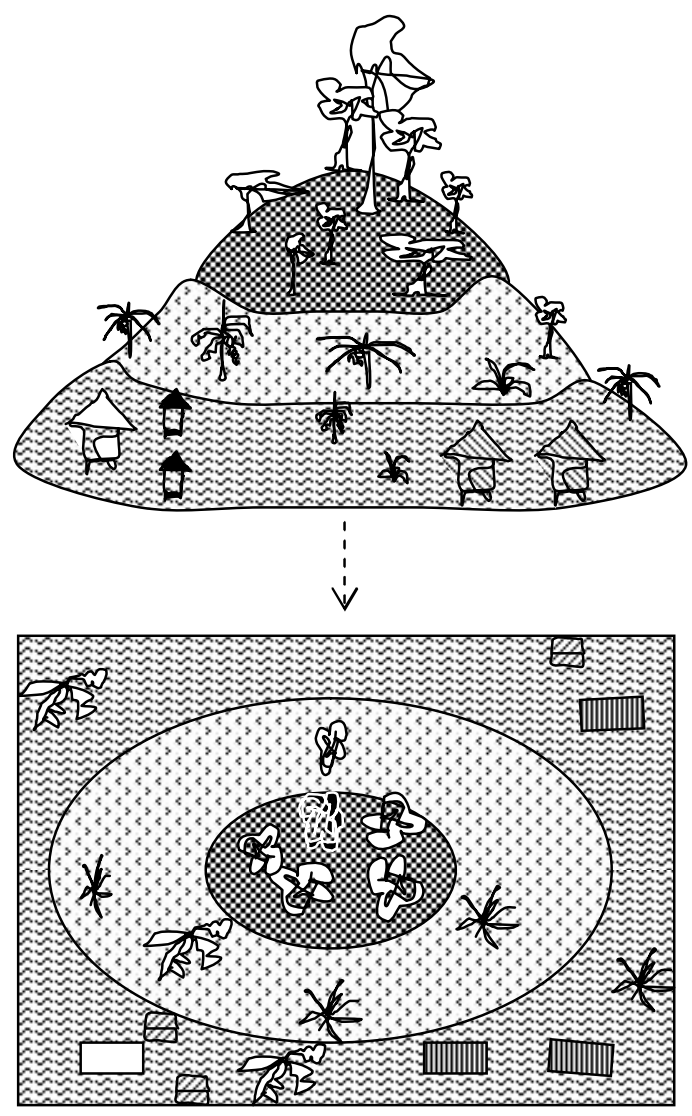

Keterangan :

\% : Zona Hutan Lindung (Leuweung Kolot)

? Zona Huma

Ficis: Zona Pemukiman

Sumber : Iskandar (1992: 32) dirubah dan disesuaikan

\section{Penutup}

Masyarakat adat sebagai penjaga dan pemelihara hutan, menganggap hutan bukan milik perseorangan melainkan sebagai milik bersama, tetapi tampaknya mereka tidak berdaya terhadap rongrongan dari luar terhadap hutan mereka, terutama pencurian kayu bahkan secara terang-terangan atas nama pemerintah setempat yang menganggap bahwa hutan tersebut adalah milik negara yang dapat diambil kayunya untuk pembangunan, seperti yang pernah terjadi pada hutan di gunung Halimun yang kayunya banyak diambil dengan alasan untuk 
pembangunan ibukota kabupaten di Pelabuanratu di awal kepindahan ibukota dari kota Sukabumi. Suatu hal yang disayangkan adalah kepemilikan hutan secara adat, tidak tertulis secara sah di BPN tetapi dianggap sebagai hak milik Negara yang akibatnya kepentingan negara menjadi alasan untuk pengambilan hutan milik masyarakat adat.

Pengambilan kayu hutan secara sembarangan apalagi secara besarbesaran dapat menurunkan daya dukung lingkungan yang akibatnya menurunkan kualitas lingkungan dan kualitas hidup masyarakat adat yang tadinya melindungi dan menjaga hutan, sebagaimana diungkapkan Poerwanto (2000:169) yaitu,

..... terlampauinya batas kemampuan lingkungan hidup sebagai sumberdaya akan mengakibatkan mutu lingkungan itu menurun. Menurunnya mutu lingkungan mutu lingkungan itu, pada giliran selanjutnya akan menyebabkan manusia yang ada di dalamnya tidak akan memperoleh mutu kehidupan yang baik dan optimal. Di sini tampak bahwa menurunnya mutu lingkungan hidup, akan menyebabkan menurunnya mutu kehidupan manusia yang ada di dalamnya. Di sisi lain, hal yang sebaliknya juga dapat terjadi, bila mutu kehidupan manusia menurun maka mutu lingkungan tempat tinggal manusia itu juga akan menurun.

Dengan demikian, bahwa kualitas hidup dan kualitas lingkungan bergerak secara timbal balik. Karena itu, keberadaan masyarakat adat harus diperhatikan melalui pengakuan Pemerintah yang di antaranya peningkatan kualitas hidup dengan cara pengakuan hak mereka atas hutan yang dilindunginya.

Masyarakat adat di Jawa Barat dan Banten yang menjaga dan memelihara hutan tersebar di beberapa daerah antara lain: Masyarakat adat Kampung Naga di Tasikmalaya; Masyarakat adat Kasepuhan di bagian Selatan Banten seperti Citorek, Cisungsanf, Guradog dll.; Masyarakat adat Kampung Kuta di Ciamis; Hutan adat di Situ Lengkong Panjalu Ciamis; dan sebagainya. Mereka sebagai masyarakat adat melalui kearifan lokal dalam menjaga hutan cukup melalui amanat leluhur yang harus dilaksanakan secara turun temurun ternyata ampuh dan mereka tidak berani untuk melanggarnya. Karena itu, masyarakat adat yang menjaga hutan lindung tampaknya kita harus bercermin dari mereka, apalagi kehidupan kita penuh dengan Peraturan dan Undang-Undang yang tegas beserta sanksi hukum ternyata tidak mampu untuk menjaga hutan walaupun dianggap sebagai milik negara. Patut kita renungkan ekspor kayu ke negara-negara Eropa dan USA yang setiap tahun beribu-ribu meter kubik, dan tidak sedikit penduduk di negara pengimpor kayu melakukan demonstrasi untuk memboikot kayu-kayu tropis sebagai akibat lalainya dalam melakukan pembaharuan hutan. Hutan Indonesia akan semakin habis, selain kayunya dijual dan terjadinya kebakaran juga tidak seimbang dengan usaha mengembalikan hutan melalui penanaman kembali.

\section{Daftar Pustaka}

Adimihardja, Kusnaka. 1992. Kasepuhan yang Tumbuh Di Atas yang Luruh: Pengelolaan lingkungan secara tradisional di kawasan Gunung Halimun Jawa Barat. Bandung: Tarsito.

Adimihardja, Kusnaka (ed). 1994. Sistem Pengetahuan dan Teknologi Rakyat: Subsistensi dan pembangunan berwawasan lingkungan di kalangan 
masyarakat Sunda di Jawa Barat. Bandung: llham Jaya.

Daeng, Hans J. 2000. Manusia, Kebudayaan, dan Lingkungan. Yogyakarta: Pustaka Pelajar.

Iskandar, Johan. 1992. Ekologi Perladangan di Indonesia: Studi kasus dari daerah Baduy Banten Selatan Jawa Barat. Jakarta: Djambatan.

Poerwamto, Hari. 2000. Kebudayaan dan Lingkungan: Dalam persepektif antropologi. Yogyakarta: Pustaka Pelajar.

Soerjani, M; Ahmad, Rofiq; dan Munir, Rozy. 1987. Lingkungan: Sumberdaya alam dan kependudukan dalam pembangunan. Jakarta: Universitas Indonesia Press. 